\title{
Annual Bloom-time Phosphorus Fertigation Affects Soil Phosphorus, Apple Tree Phosphorus Nutrition, Yield, and Fruit Quality
}

\author{
Gerry H. Neilsen ${ }^{1,3}$, Denise Neilsen ${ }^{1}$, Peter Toivonen', \\ and Linda Herbert ${ }^{2}$ \\ Agriculture and Agri-Food Canada, Pacific Agri-Food Research Centre, \\ 4200 Highway 97, Summerland, British Columbia, Canada VOH 1 Z0
}

Additional index words. antioxidant content, browning, leaf and fruit $\mathrm{P}$, water core

\begin{abstract}
A randomized, complete block, split-plot experimental design with six replicates was established and maintained annually for the first five fruiting seasons (1999 to 2003) in a high-density apple [Malus sylvestris (L) Mill var. domestica (Borkh.) Mansf] orchard on M.9 rootstock planted in Apr. 1998. Main plot treatments involved eight different nutrient regimes, each containing three tree subplots of each of five different cultivars (Ambrosia, Cameo, Fuji, Gala, and Silken). This report compares a + phosphorus (P) treatment, involving annual fertigation at bloom time of $20 \mathrm{~g} \mathrm{P} /$ tree as ammonium polyphosphate $(10 \mathrm{~N}-15 \mathrm{P}-0 \mathrm{~K})$, to a $-\mathrm{P}$ treatment. Both treatments also received nitrogen, potassium, and boron nutrients through fertigation. Drip fertigation of $P$ increased $2 \mathrm{M}$ KCl-extractable $P$ to $0.4-\mathrm{m}$ depth within $0.5-\mathrm{m}$ distance of the drippers. Leaf and fruit $P$ concentrations were consistently increased by the $+P$ treatment with few differences among cultivars. P-fertigated trees also had a $\mathbf{2 0 \%}$ increase in cumulative yield overall cultivars during the first five fruiting seasons. Standard fruit quality measurements, including fruit size, soluble solids concentration, titratable acidity, and red coloration were unaffected by $P$ application. However, reductions in incidence of water core at harvest, increased resistance to browning, and elevated antioxidant content of harvested fruit measured in some years imply a role for $P$ in apple membrane stability. The cumulative results indicate that applications of $20 \mathrm{~g} P$ as ammonium polyphosphate annually at bloom would be advantageous for apples receiving adequate fertigated applications of nitrogen, potassium, and boron. Best apple performance was associated with leaf $P$ concentrations above $2.2 \mathrm{mg} \cdot \mathrm{g}^{-1}$ dry weight and fruit $P$ concentrations between 100 and $120 \mathrm{mg} \cdot \mathrm{kg}^{-1}$ dry weight.
\end{abstract}

Phosphorus fertilization of apple orchards has received much less attention than nitrogen $(\mathrm{N})$ and potassium $(\mathrm{K})$ fertilization as a result of limited reports of positive responses to phosphorus $(\mathrm{P})$ fertilization in the historical literature (Boyton and Oberly, 1966). Furthermore, unit area whole tree $\mathrm{P}$ nutrient demands have been calculated to be low, $\approx 20 \mathrm{~kg} \cdot \mathrm{ha}^{-1}$ for 14-year-old 'Golden Delicious' apple trees yielding $90 \mathrm{t} \cdot \mathrm{ha}^{-1}$ spaced at 500 trees/ha in contrast with much higher $\mathrm{N}$ $\left(\approx 120 \mathrm{~kg} \cdot \mathrm{ha}^{-1}\right)$ and $\mathrm{K}\left(\approx 200 \mathrm{~kg} \cdot \mathrm{ha}^{-1}\right)$ requirements (Neilsen and Neilsen, 2003). Few nutrient estimates are available for high-

\footnotetext{
Received for publication 4 Jan. 2008. Accepted for publication $30 \mathrm{Jan} .2008$.

Funding for this research was provided by the Washington Tree Fruit Research Commission and matched by Agriculture and Agri-Food Canada's Matching Investment Initiative (MII) program. We thank Judy Braumberger, Brian Drought, David Gregory, Brenda Lannard, Istvan Losso, Andrea Martin, and Bill Rabie for technical assistance.

${ }^{1}$ Research Scientists.

${ }^{2}$ Research Technician

${ }^{3}$ To whom reprint requests should be addressed; e-mail neilseng@agr.gc.ca
}

density plantings, which can approach 4000 trees/ha for 'super spindle'.

More recently, several conditions have been identified when apples respond to $\mathrm{P}$ fertilization. These include times when apple root length is limited, as when trees are newly planted (Taylor and Goubran, 1975) and when replant disorders further inhibit root growth (Neilsen and Yorston, 1991), or when low soil $\mathrm{P}$ levels limit $\mathrm{P}$ availability to roots (Cripps, 1987; Raese, 1998). Responses to $\mathrm{P}$ application have included increased vigor and accelerated flowering of newly planted trees (Neilsen et al., 1990; Taylor and Goubran, 1975) and increased cropping and increased $\mathrm{P}$ concentrations in leaf and fruit tissue of mature trees (Cripps, 1987; Raese, 1998). Foliar sprays of soluble $P$ compounds have increased fruit $\mathrm{P}$ concentrations and reduced susceptibility to low temperature breakdown (LTB) in 'Cox's Orange' (Johnson and Yogoratnam, 1978) and LTB and firmness of 'McIntosh' apples (Webster and Lidster, 1986), but it is not known whether soil $\mathrm{P}$ applications would result in similar improvements in fruit quality. Responsiveness to $\mathrm{P}$ fertilization has often been made difficult by the absence of unique leaf $\mathrm{P}$ deficiency symptoms at low tissue P concentrations (Benson and Covey, 1979). Little is known about the seasonal requirements for $\mathrm{P}$, although these cumulative responses suggest that apple $\mathrm{P}$ demand may peak at a time of intense cell division and meristematic activity as might occur in spring when simultaneous strong fruit, root, and shoot growth occurs.

Drip fertigation has improved the availability of P to apple trees (Neilsen et al., 1999) by allowing mass flow delivery of high $P$ concentrations directly to the root surface and thereby proving as effective at increasing first-year tree $\mathrm{P}$ uptake as $\mathrm{P}$ application in the planting hole (Neilsen et al., 1993). P fertigation has therefore become a standard firstyear recommendation for growers in southern interior British Columbia (BC) (BC Ministry of Agriculture and Lands, 2007). However, little is known of the persistence of the effect when $\mathrm{P}$ is fertigated annually.

This study was undertaken to measure the effect of a single annual $\mathrm{P}$ application through fertigation at bloom on performance of a range of potentially important, nontraditional apple cultivars planted at high density on a dwarfing rootstock. Assessment of soil and tree $\mathrm{P}$ status and apple yield and quality response was emphasized.

\section{Materials and Methods}

In Apr. 1998, an experimental block of five apple [Malus sylvestris (L) Mill var domestica (Borkh.) Mansf] cultivars (Ambrosia, Cameo, Fuji, Gala, and Silken) were planted at high density on the dwarfing rootstock M.9 in rows separated by $3 \mathrm{~m}$ with $1 \mathrm{~m}$ between trees in each row. In the first year, all trees were fertigated with the industry standard NP regime involving daily application of calcium nitrate $(15.5 \mathrm{~N}-0 \mathrm{P}-0 \mathrm{~K}$; cumulative $47 \mathrm{~g} \mathrm{~N}$ per tree) within 8 weeks of planting and $20 \mathrm{~g} \mathrm{P}$ per tree as ammonium polyphosphate $(10 \mathrm{~N}-15 \mathrm{P}-0 \mathrm{~K})$ soon after planting on 4 June 1998. Beginning in 1999, a randomized complete block, splitplot experimental design was imposed and maintained for the next five growing seasons. Main plots comprised of eight different fertigation regimes, whereas subplots consisted of the five apple cultivars, previously indicated, randomly planted in three-tree plots in each of the six replications for each fertigation treatment. Two border apple trees separated each main plot fertigation treatment and border rows were planted to completely surround the experimental block. Pertinent to this article were two fertigation treatments, which compared the presence $(+\mathrm{P})$ or absence $(-\mathrm{P})$ of $\mathrm{P}$ in otherwise comparable fertigation treatments involving annual applications totaling $\approx 0.17$ g boron (B) per tree (except 1999 when $\approx 0.5 \mathrm{~g} \mathrm{~B}$ was applied per tree) and $\mathrm{N}$ (application of 160 $\mathrm{mg} \cdot \mathrm{L}^{-1} \mathrm{~N}$ as calcium nitrate) both applied daily from 0 to 4 weeks post full bloom (pfb). Potassium as potassium chloride was also fertigated daily from 4 to 8 weeks pfb supplying $\approx 20 \mathrm{~g} \mathrm{~K}$ per tree per year. The $+\mathrm{P}$ treatment involved a single $\mathrm{P}$ application 
of $20 \mathrm{~g}$ P per tree of ammonium polyphosphate, annually soon after bloom (based on the 'Ambrosia' cultivar) on 21, 25, 24, 16, and 16 of May 1999 to 2003, respectively. Each fertigation treatment had a separate irrigation line with emitters installed on the appropriate line according to the experimental randomization. Each treatment tree was irrigated by two $4-\mathrm{L} \cdot \mathrm{h}^{-1}$ pressure-compensating emitters (The Toro Company, El Cajon, CA) placed $0.3 \mathrm{~m}$ either side of the tree in the tree row. To minimize water stress, irrigation was applied daily in response to the previous day's evapotranspiration demand and automatically scheduled by atmometer so that water application varied directly in response to evaporative demand (Parchomchuk et al., 1996).

Trees were trained to a slender spindle system supported by posts and grown in a 2.0-m-wide herbicide strip maintained by applications of $1 \mathrm{~kg} \cdot \mathrm{ha}^{-1}$ glyphosate each year in early May, midsummer, and early fall. Conventional foliar application of zinc and insect and disease control procedures followed standard commercial recommendations (BC Ministry of Agriculture and Lands, 2007).

The experimental site was located on a Skaha loamy sand (Wittneben, 1986), an Aridic Haploxeroll, extensively planted to orchards or vineyards in southern British Columbia. Coarse-textured soils such as these have limited nutrient and waterholding capacities and have previously been shown to be susceptible to the development of $\mathrm{K}$ and $\mathrm{B}$ deficiency under drip irrigation (Neilsen et al., 1995).

Composite samples of 30 leaves from the midportion of extension shoots of the current year's growth from each tree of the three tree plots were collected 15 July, 20 July, 18 July, 11 July, and 7 July 1999 to 2003, respectively, $\approx 8$ weeks after full bloom (based on the 'Ambrosia' cultivar). For the 'Fuji' cultivar, similar leaf samples were collected 4 weeks (2000 to 2003) and 12 weeks (1999 to 2003) after full bloom. All samples were oven-dried at $65^{\circ} \mathrm{C}$ and ground in a stainless steel mill. From 1999 to 2001, a 250-mg subsample was digested for $0.75 \mathrm{~h}$ on a block digester at $350{ }^{\circ} \mathrm{C}$ in a $\mathrm{H}_{2} \mathrm{SO}_{4}$ solution containing $\mathrm{K}_{2} \mathrm{SO}_{4}$ and $\mathrm{HgO}$. Nitrogen in the digest was determined through the formation of an ammonium-salicylate complex and $\mathrm{P}$ was determined through the formation of a phosphomolybdenum blue complex (Technicon Autoanalyzer II Industrial Method No. 334-74 A/A; Technicon, Elmsford, NY). In 2002 and 2003, leaf nitrogen was determined using the LECO FP-528 (Leco Corporation, St. Joseph, MI) combustion analyzer (Sweeney and Rexroad, 1987). In both these years, 0.5-g samples were dry-ashed at $525{ }^{\circ} \mathrm{C}$ and dissolved in $1.2 \mathrm{M} \mathrm{HCl}$ before determination of $\mathrm{P}$ by inductively coupled argon plasma (ICP) spectrophotometry.

The number and weight of harvested fruit were measured each year at commercial maturity (for the respective cultivar) for each plot and replicate for the two P treatments, 1999 to 2003. Each year, a randomly selected 10-apple subsample from each plot was evaluated for skin color, flesh firmness, titratable acidity (TA), and soluble solids concentration (SSC). Percent red skin color (except for the yellow-skinned cultivar 'Silken') was estimated visually. Flesh firmness was determined with a Baullaf (Lake City Technical Products Ltd., Kelowna, BC, Canada) penetrometer (11.1-mm diameter tip). Soluble solids concentration in the juice was measured with a refractometer and TA was determined by titration of juice with $0.1 \mathrm{M}$ $\mathrm{NaOH}$ to an $8.1 \mathrm{pH}$ end point. Juice was obtained from a mechanical juicer, which macerated sectors taken from each apple in the 10-fruit subsample. The occurrence of water core was determined visually on crosssections of harvested fruit.

A random sample of 25 fruit was selected at harvest from each treatment, cultivar, and replicate and rinsed under running, distilled water and then air-dried. Stem tissue and seeds were removed and opposite, unpeeled quarters were blended with 1.5 times their weight of distilled water. A $150-\mathrm{mL}$ subsample was further homogenized with a highspeed tissue homogenizer. A weighed 9-mL subsample of homogenized slurry was digested in $5.4 \mathrm{~mL}$ of concentrated $\mathrm{H}_{2} \mathrm{SO}_{4}$ containing $\mathrm{Na}_{2} \mathrm{SO}_{4}(1.8 \mathrm{~g})$, copper $(0.36 \mathrm{~mL}$ $25 \% \mathrm{CuSO}_{4}$ solution), and selenium (0.67 $\left.\mathrm{g} \cdot \mathrm{L}^{-1}\right)$ at $380{ }^{\circ} \mathrm{C}$ for $1 \mathrm{~h}$. Calcium was determined in these extracts through atomic absorption spectrophotometry. P was determined through colorimetric or ICP methods as described for the leaf samples. In the years of lowest fruit $\mathrm{P}$ concentration in 2001 and 2002, additional fruit quality assessments were made on harvested fruit held for $90 \mathrm{~d}$ at $1{ }^{\circ} \mathrm{C}$ in air. After the storage period, membrane leakage was determined for 'Fuji' and 'Silken' cultivars. Five apples per replicate of each treatment were randomly selected and cut into wedges using an eightslice corer-wedger. One slice from each apple was randomly selected and a core was cut transversally through the cortical tissue of each slice using a $1-\mathrm{cm}$ diameter cork borer. The ends of each core were removed using a new razor blade and three 2-mm discs were cut from the remainder of each core. A total of 15 discs were placed in 25-mL Erlenmeyer flasks and rinsed three times with $\mathrm{dH}_{2} \mathrm{O}$. A 25-mL aliquot of $0.4 \mathrm{M} \mathrm{d}$-mannitol (isotonic with tissue) was added and the flask was then placed in an orbital shaker set at $100 \mathrm{rpm}$ for $1 \mathrm{~h}$. The bathing solution was decanted into a quartz cuvette and read $280 \mathrm{~nm}$ with a Beckman DU640 uv/vis spectrophotometer (Beckman Coulter Canada Ltd., Mississauga, ON, Canada). The solution was returned to the flask, and it was placed into the freezer overnight. On the next day, the flasks were thawed in cold water and the bathing solution was again decanted and read using the spectrophotometer. The relative leakage was calculated as the ratio of the first absorbance reading to the second (postfreezing) absorbance.

For 'Fuji' in 2001 to 2002, and all cultivars in 2002, water-soluble and lipid soluble antioxidant content was determined.
A sample consisting of five fruits per replicate were cut longitudinally into 12 slices and the seeds and core removed with a sharp stainless steel paring knife. Three slices from each of five fruit were then segregated into a bulk replicate sample containing $400 \mathrm{~g}$ of cortical tissue. Slices were dropped in liquid nitrogen and powdered with a freezer mill. The frozen powder was individually kept in a sealed plastic bottle and stored at $-80{ }^{\circ} \mathrm{C}$ until used for analyses.

To measure water-soluble antioxidant content, $5 \mathrm{~g}$ powdered, frozen tissue was added to $20 \mathrm{~mL}$ of chilled $\mathrm{dH}_{2} \mathrm{O}$ (chilled to $4{ }^{\circ} \mathrm{C}$ ) and homogenized with a model PT 10/35 Polytron homogenizer (Brinkmann Instruments, Rexdale, Ontario, Canada) at a speed setting of four for $30 \mathrm{~s}$. The resultant slurry was centrifuged at $15,000 \times g$ for $15 \mathrm{~min}$ and the supernatant decanted into a clean test tube. This was then diluted 1:9 in $\mathrm{dH}_{2} 0$. A $0.5-\mathrm{mL}$ aliquot of the resultant diluted extract was added to $1 \mathrm{~mL}$ of $0.2 \mathrm{~mm} 2,2$-diphenyl-1picrylhyrazyl (DPPH) in ethanol and the tube was vortexed to ensure good mixing. After 15 min, the absorbance was read at $517 \mathrm{~nm}$ using a Beckmann DU640 uv/vis spectrophometer (Fullerton, CA). The blank for these readings

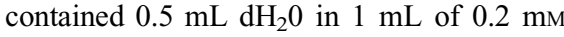
DPPH and the absorbance response calibrated against standard solutions of ascorbic acid.

To measure lipid soluble antioxidant content, $5 \mathrm{~g}$ powdered frozen tissue was homogenized in $10 \mathrm{~mL}$ of hexane. The resultant slurry was centrifuged for $20 \mathrm{~min}$ at $15,000 \times$ $g$ and the supernatant was decanted and then dried in the dark under a stream of $\mathrm{N}_{2}$ at room temperature. The residue was then redissolved in ethanol and brought to a $2-\mathrm{mL}$ total volume. A $0.5-\mathrm{mL}$ aliquot of the resultant diluted extract was added to $1 \mathrm{~mL}$ of $0.2 \mathrm{~mm}$ DPPH and analyzed as described previously. The blank for these readings contained $0.5 \mathrm{~mL}$ ethanol in $1 \mathrm{~mL}$ of $0.2 \mathrm{~mm} \mathrm{DPPH}$ and the absorbance response calibrated against standard solutions of $\alpha$-tocopherol.

In 2002, for all cultivars, a sample of three apples were sliced into eight wedges using a Dito Dean apple corer-wedger (Rocklin, CA), washed in chlorinated tap water (100 ppm total chlorine), and then placed into $18 \times$ 20-mm low-density polyethylene zip-lock bags of $17-\mu \mathrm{m}$ thickness. The packages containing apple slices were placed into $1{ }^{\circ} \mathrm{C}$ storage. After $7 \mathrm{~d}$, the packages were removed from storage; apple slices were removed and assessed for cut-edge browning. Previous research indicated cut-edge browning is stable between 7 and $21 \mathrm{~d}$ after cutting (Toivonen et al., 2003). Lightness value for each slice was determined using a Minolta chroma-meter (CR 300; Minolta, Ramsey, $\mathrm{NJ})$ using the $\mathrm{L}^{*}$ values of the Commission de l'Elairage color system (Gil et al., 1998). Lightness readings were taken at three points on each side of the slice (near the calyx end, in the middle, and near the stem end) to give six values per slice. These six values per slice were averaged into one number, which was used as the single replicate value in subsequent statistical analyses. 
Before the termination of the experiment (and removal of trees), soil sampling was undertaken in Spring 2005 at three different distances $(0,0.5$, and $1.0 \mathrm{~m})$ perpendicular to the tree rows from one of the drip emitters for the centrally located 'Fuji' tree for five replicates of each of the two $\mathrm{P}$ treatments $( \pm \mathrm{P})$. At each distance, soil samples were collected at $0.1-\mathrm{m}$ depth increments beginning at the soil surface ( 0 to $0.1 \mathrm{~m})$ and extending to the 0.5 - to $0.6-\mathrm{m}$ soil layer. Soil samples were placed in cold storage at $4{ }^{\circ} \mathrm{C}$ until analyses. Twenty grams of moist soil was extracted in $100 \mathrm{~mL}$ of $2.0 \mathrm{M} \mathrm{KCl}$ for $1 \mathrm{~h}$ before filtration and determination of $\mathrm{NO}_{3}-\mathrm{N}$, $\mathrm{NH}_{4}-\mathrm{N}$, and $\mathrm{PO}_{4}-\mathrm{P}$ using a flow injection analyzer and manufacturer's procedures (O.I. Analytical, College Station, TX). pH was determined on a $10-\mathrm{g}$ soil sample after equilibration in $20 \mathrm{~mL}$ of water for $30 \mathrm{~min}$.

Analysis of variance was performed on all leaf and fruit nutrients, yield, and fruit quality characteristics according to the experimental design (SAS, 1989). Data were analyzed as a split-plot design with six replicates and fertigation as main plot treatments with individual degree of freedom contrasts comparing $+\mathrm{P}$ and $-\mathrm{P}$ treatments. Subplots were random three-tree plots of each of the five different cultivars. Percent data (red color, incidence of water core) were arcsine-transformed before analyses. As expected, cultivar (subplots) effects were significant for nearly all years and parameters, indicating a significant genetic influence on plant characteristics. Of interest to this discussion were significant treatment $(\mathrm{P})$ and treatment $\times$ cultivar interactions. Data were analyzed separately by year as a result of the transition of the plots from primarily vegetative to fruiting growth over the 5-year experimental period. Soil nutrients (samples only from the 'Fuji' plots, a single time) were analyzed separately as a randomized complete block with two treatments $( \pm \mathrm{P})$ and five replicates.

\section{Results and Discussion}

Soil effects. Extractable soil P concentrations were elevated by the annual ammonium polyphosphate treatment $(+\mathrm{P})$ when measured before removal of the experimental trees in 2005. Soil P was significantly increased directly beneath the drip emitters for each $0.1-\mathrm{m}$ depth increment to $0.4-\mathrm{m}$ depth (Fig. 1A). A similar pattern was measured at $0.5 \mathrm{~m}$ from the emitters perpendicular to the tree row, except that the increase was not significant at $0.1-$ to $0.2-\mathrm{m}$ depth (Fig. 1B). There were no differences in profile $\mathrm{P}$ concentration at $1-\mathrm{m}$ distance from the emitter location (Fig. 1C). In general, extractable soil $\mathrm{P}$ concentration increased below $0.5-\mathrm{m}$ depth at all distances from the emitter. There were no significant effects of treatments on soil $\mathrm{NO}_{3}-\mathrm{N}$ and $\mathrm{NH}_{4}-\mathrm{N}$ concentrations measured in the same extract (as $\mathrm{P}$ ) at any distance or depth relative to the emitters (data not shown). Soil $\mathrm{NH}_{4}-\mathrm{N}$ concentrations were near zero, whereas soil $\mathrm{NO}_{3}-\mathrm{N}$ concentrations averaged $0.20,0.45$, and 0.50

Extractable P $\left(\mathrm{mg} \mathrm{kg}^{-1}\right)$

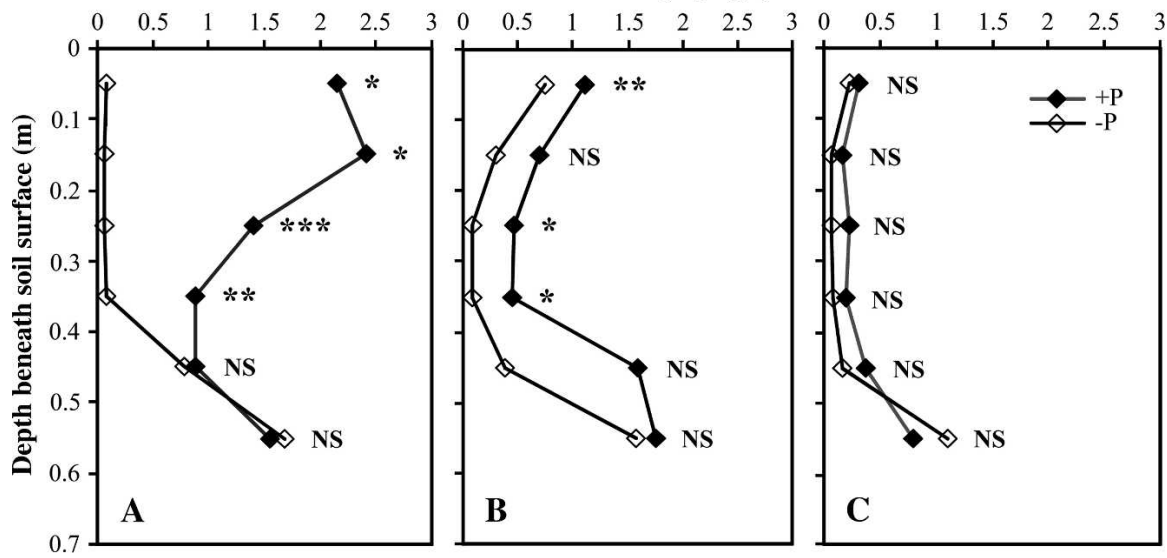

Fig. 1. Soil phosphorus $(\mathrm{P})$ as extracted in $\mathrm{KCl}$ measured at various depths beneath the soil surface for the $+\mathrm{P}$ and $-\mathrm{P}$ treatment $(\mathbf{A})$ directly beneath the in-row drip emitters, $(\mathbf{B}) 0.5$ and $(\mathbf{C}) 1.0 \mathrm{~m}$ from the emitters perpendicular to the tree rows. Paired means significantly different at $P=0.001(* * *)$, $0.01(* *), 0.05(*)$, or nonsignificantly different (NS).

$\mathrm{mg} \cdot \mathrm{kg}^{-1}$ across all depths at $0,0.5$, and 1.0 $\mathrm{m}$ from the drip emitter. Similarly, soil $\mathrm{pH}$ changes associated with treatments were minimal with a single occurrence of a significant $\mathrm{pH}$ decrease from $7.2(-\mathrm{P})$ to 7.0 associated with the $\mathrm{P}$ treatment directly beneath the emitter at $0.1-$ to $0.2-\mathrm{m}$ depth. $\mathrm{pH}$ values also increased from near 7 (at the surface) to near 8 at $0.4-$ to $0.6-\mathrm{m}$ depth.

Mobility of annual bloom time applications of fertigated ammonium polyphosphate within $0.5-\mathrm{m}$ radial distance of the drip emitters is indicated by the elevated $2 \mathrm{M}$ $\mathrm{KCl}$-extractable $\mathrm{P}$ concentrations to $0.4-\mathrm{m}$ depth. Increased mobility of $P$ dissolved in irrigation water has been previously reported for sandy soils (O'Neil et al., 1979). It is likely that this $\mathrm{P}$ would have been highly available to the apple trees because previous research on this soil series indicated a clustering of roots near and immediately below drip emitters (Neilsen et al., 1997). For example, after 5 years, the average root location occurred at $\approx 0.25 \mathrm{~m}$ depth and lateral distance from the drip emitter location for 'McIntosh' receiving N-P fertigation and growing on the same M.9 rootstock. The modest increases in $2 \mathrm{M} \mathrm{KCl}$-extractable soil $\mathrm{P}$ (not exceeding an average of $2.5 \mathrm{mg} \cdot \mathrm{kg}^{-1}$ ) resulting from the $+\mathrm{P}$ treatment nevertheless exceeded soil solution $\mathrm{P}$ concentrations previously measured for this soil when it had not received fertilizer $P$ applications (Neilsen et al., 1993). These measurements were made at the end of the study and represented the situation after the cumulative application of $80 \mathrm{~g}$ P per emitter ( 8 years $\times 10 \mathrm{~g} \mathrm{P} /$ emitter $)$ or $\approx 125 \mathrm{~kg} \cdot \mathrm{ha}^{-1} \mathrm{P}$ assuming uniform wetting within an $0.5-\mathrm{m}$ radius of each emitter. Previous research has indicated that the Langmuir adsorption maxima for this soil is typical of loamy sands in the region (158 $\mathrm{mg} \cdot \mathrm{kg}^{-1} \mathrm{P}$ ) and that solution $\mathrm{P}$ concentrations after single-dose incubations remain elevated for 12 weeks (Neilsen et al., 1993). Thus, the method of $\mathrm{P}$ fertigation in this study should have sufficed to significantly increase annual, early-season P uptake for these apple trees.
Application of ammonium polyphosphate in the $+\mathrm{P}$ treatment resulted in coapplication of $13.3 \mathrm{~g} \mathrm{~N}$ per tree in the $\mathrm{NH}_{4}-\mathrm{N}$ form at bloom. The $\mathrm{N}$ regime was otherwise similar for the two treatments, involving maintenance of a $\mathrm{NO}_{3}-\mathrm{N}$ concentration of 168 $\mathrm{mg} \cdot \mathrm{L}^{-1}$ in the fertigating solution daily for 4 weeks pfb. Hence, the amount of $\mathrm{N}$ applied per tree varied with the amount of water applied but, on average, in 1999 to 2003, was $46.7 \mathrm{~g} \mathrm{~N}$ per tree per year. Thus, although the $\mathrm{P}$ treatment received $28.5 \%$ more $\mathrm{N}$ per tree as $\mathrm{NH}_{4}-\mathrm{N}$, its effectiveness was limited by the short duration of its application. Previous research has indicated that when $\mathrm{NH}_{4}-\mathrm{N}$ is fertigated, soil solution $\mathrm{NO}_{3}-\mathrm{N}$ concentration increase is delayed (Neilsen et al., 1999). Furthermore, only low amounts of $\mathrm{NH}_{4}-\mathrm{N}$ are measurable in the soil after fertigating all $\mathrm{N}$ as $\mathrm{NH}_{4}-\mathrm{N}$ (Klein and Spieler, 1987). Also, the amount of applied irrigation water has a direct effect on root zone soil solution $\mathrm{NO}_{3}-\mathrm{N}$ concentrations, which are rapidly reduced to low values after cessation of fertigation and continued irrigation (Neilsen et al., 1998). The negligible $2 \mathrm{M} \mathrm{KCl}$-extractable $\mathrm{NH}_{4}-\mathrm{N}$ values measured at the end of the study for both treatments are consistent with previous results and provide further evidence that effective $\mathrm{N}$ regimes may not have differed widely between $P$ treatments.

Rapid acidification of sandy soils beneath drip emitters in response to fertigation with ammonium-based fertilizers has been long recognized (Edwards et al., 1982) and was the rationale for use of calcium nitrate as the primary $\mathrm{N}$ fertigation source in this study. The limited decline in soil $\mathrm{pH}$ associated with eight annual, bloom-time applications of ammonium polyphosphate indicates this method of $\mathrm{P}$ fertigation should be sustainable with minimal consequences to soil acidification.

Tree nutrition. Annual fertigation of a single-time application of ammonium polyphosphate at bloom early in the growing season consistently increased midterminal, midsummer leaf $\mathrm{P}$ concentration above 2.0 $\mathrm{mg} \cdot \mathrm{g}^{-1}$ dry weight for all cultivars in the first 
five growing seasons (Table 1). Increases were particularly pronounced early in the growing season (4 weeks pfb) as indicated by samples taken during the growing season for the 'Fuji' cultivar (Fig. 2). In the first 2 years (1999 and 2000), leaf $P$ was unaffected when measured as late as 12 weeks pfb. Subsequently, samples collected at 12 weeks, 2001 to 2003, also had increased leaf P concentration resulting from bloom time $\mathrm{P}$ fertigation. In two of the first five growing seasons, midsummer ( 8 weeks pfb) leaf $\mathrm{N}$ concentration was significantly increased across all apple cultivars for the $+\mathrm{P}$ compared with the $-\mathrm{P}$ treatments (Table 1 ).

At the time of commercial harvest, fruit $\mathrm{P}$ concentration was usually increased by $\mathrm{P}$ fertigation for all apple cultivars (Table 2). The single exception was for 'Gala' in 2001, which, unlike the other four cultivars in this year, did not show a significant increase in fruit $\mathrm{P}$ concentration. In contrast, fruit $\mathrm{N}$ concentrations were minimally affected by treatments (data not shown). Only in the first year of the study (1999) was fruit $\mathrm{N}$ concentration increased from $51.6 \mathrm{mg} \cdot \mathrm{kg}^{-1}$ fresh weight (fw) (-P) to $60.1 \mathrm{mg} \cdot \mathrm{kg}^{-1} \mathrm{fw}(+\mathrm{P})$; otherwise (2000 to 2003), fruit $\mathrm{N}$ concentration was unaffected by $\mathrm{P}$ application.

The single-time fertigated application of $\mathrm{P}$ generally improved the $\mathrm{P}$ nutrition of both vegetative (leaf) and reproductive (fruit) tissue indicating that $\mathrm{P}$ applied in this way was readily available to all the apple cultivars tested. The increased tissue $\mathrm{P}$ concentrations were consistent with increases in soil-extractable $\mathrm{P}$ concentration measured at the end of the study for the $\mathrm{P}$ fertigation treatment. It is noteworthy that all leaf $\mathrm{P}$ concentrations, regardless of $\mathrm{P}$ treatment, exceeded 1.5 $\mathrm{mg} \cdot \mathrm{g}^{-1}$ dry weight (dw), normally considered adequate for apples (Shear and Faust, 1980). Higher optimum leaf $\mathrm{P}$ concentrations of $2.5 \mathrm{mg} \cdot \mathrm{g}^{-1} \mathrm{dw}$ have been advocated for mature trees based on sand culture studies using potted trees (Bould and Parfitt, 1973). High leaf $\mathrm{P}$ concentrations (around and exceeding $3.0 \mathrm{mg} \cdot \mathrm{g}^{-1} \mathrm{dw}$ ) have been advocated to stimulate flowering, initial vigor, and yield of newly planted trees (Neilsen et al., 1990; Taylor and Goubran, 1975). Fruit P concentration of P-fertigated fruit always exceeded $100 \mathrm{mg} \cdot \mathrm{kg}^{-1}$ fw and often was above 120

Table 1. Leaf nitrogen $(\mathrm{N})$ and phosphorus $(\mathrm{P})$ concentration ( 8 weeks post full bloom) for apple cultivars (Ambrosia, Cameo, Fuji, Gala, and Silken) as affected by fertigation of $20 \mathrm{~g} \mathrm{P}$ as ammonium polyphosphate $(+\mathrm{P})$ or not $(-\mathrm{P})$ immediately after bloom, 1999 to 2003.

\begin{tabular}{lccccc}
\hline Treatment & 1999 & 2000 & 2001 & 2002 & 2003 \\
\hline \multirow{5}{c}{ Leaf N $\left(\mathrm{mg} \cdot \mathrm{g}^{-1} \mathrm{dw}\right)$} \\
$+\mathrm{P}$ & 26.3 & 26.6 & 24.3 & 27.0 & 22.0 \\
$-\mathrm{P}$ & 24.8 & 25.3 & 24.4 & 25.8 & 21.9 \\
Significance & $\mathrm{NS}$ & $*$ & $\mathrm{NS}$ & $*$ & $\mathrm{NS}$ \\
& \multicolumn{5}{c}{ Leaf $\mathrm{P}\left(\mathrm{mg} \cdot \mathrm{g}^{-1} \mathrm{dw}\right)$} \\
$+\mathrm{P}$ & 2.6 & 2.7 & 2.3 & 2.2 & 2.2 \\
$-\mathrm{P}$ & 2.1 & 1.9 & 1.8 & 1.7 & 1.8 \\
Significance & $* * * *$ & $* * * *$ & $* *$ & $* * * *$ & $* * *$ \\
\hline Ns,********,**** Nonsignificant & or paired & means \\
significantly different at $P=0.05,0.01,0.001$, or \\
0.0001, respectively.
\end{tabular}

$\mathrm{mg} \cdot \mathrm{kg}^{-1} \mathrm{fw}$, whereas, after the first year of the study (1999), fruit not receiving $P$ usually had concentrations $\approx 100 \mathrm{mg} \cdot \mathrm{kg}^{-1} \mathrm{fw}$ or lower. Few fruit $\mathrm{P}$ thresholds have been developed for apple, although whole fruit $\mathrm{P}$ concentrations above $110 \mathrm{mg} \cdot \mathrm{kg}^{-1}$ fw have been recommended for cultivars susceptible to low-temperature breakdown (Neilsen and Neilsen, 2003). In an extensive study (3 years, 90 orchards) of traditional apple cultivars (McIntosh', 'Spartan,' and 'Golden Delicious') in the fruit-growing region of southern British Columbia, harvest fruit $\mathrm{P}$ concentration averaged $100 \mathrm{mg} \cdot \mathrm{kg}^{-1} \mathrm{fw}$ (Wolk et al., 1998). These concentrations were similar to fruit in this study not receiving $\mathrm{P}$.

Despite the additional $\mathrm{N}$ applied in the $+\mathrm{P}$ treatment, effects on tree $\mathrm{N}$ status were minimal, being limited to 2 years of increased leaf $\mathrm{N}$ concentration and a single year of increased fruit N. Furthermore, all leaf N concentrations, regardless of treatment, were consistently above the 19 to $24 \mathrm{mg} \cdot \mathrm{g}^{-1} \mathrm{dw}$ range considered adequate for apples (BC Ministry of Agriculture and Lands, 2007). This evidence suggests early-season, singletime application of $20 \mathrm{~g} \mathrm{P} /$ tree as ammonium polyphosphate is unlikely to meaningfully affect $\mathrm{N}$ nutrition of trees already receiving high levels of fertigated $\mathrm{N}$.

Yield. Both cumulative fruit number and per tree yield over the first five harvests was increased by $\mathrm{P}$ fertigation (Table 3 ). There was no overall effect on apple fruit size. When considering annual patterns, significantly increased yield resulting from $\mathrm{P}$ application was measured for 'Ambrosia' in 2001 and for all cultivars in 2000 and 2003. Increased fruit number was measured for 'Ambrosia' and 'Fuji' in 2001 and for all cultivars in 2003. There were few effects of $P$ on average fruit size except in 1999, the first fruiting year when fruit size, averaged overall cultivars, was increased by $\approx 14 \%$.

Yield response to $\mathrm{P}$ fertilization has not been widely reported historically for tree fruits, which have low unit area demands for P (Boyton and Oberly, 1966). Nevertheless, exceptions have been observed, including multiyear effects of planting time superphosphate applications, which increased tree growth, fruit set, and yield in Australia (Taylor and Goubran, 1975). Annual superphosphate applications were recommended for apple orchards grown on high P-fixing soils in western Australia where a decadelong study (1973 to 1982) indicated lack of P was the main limiting factor for growth and cropping (Cripps, 1987). Similarly, in the major fruit-growing region of the Pacific Northwest of North America, cumulative research identified numerous apple and pear orchards where tree vigor and $\mathrm{P}$ composition of leaves and fruit was increased primarily by

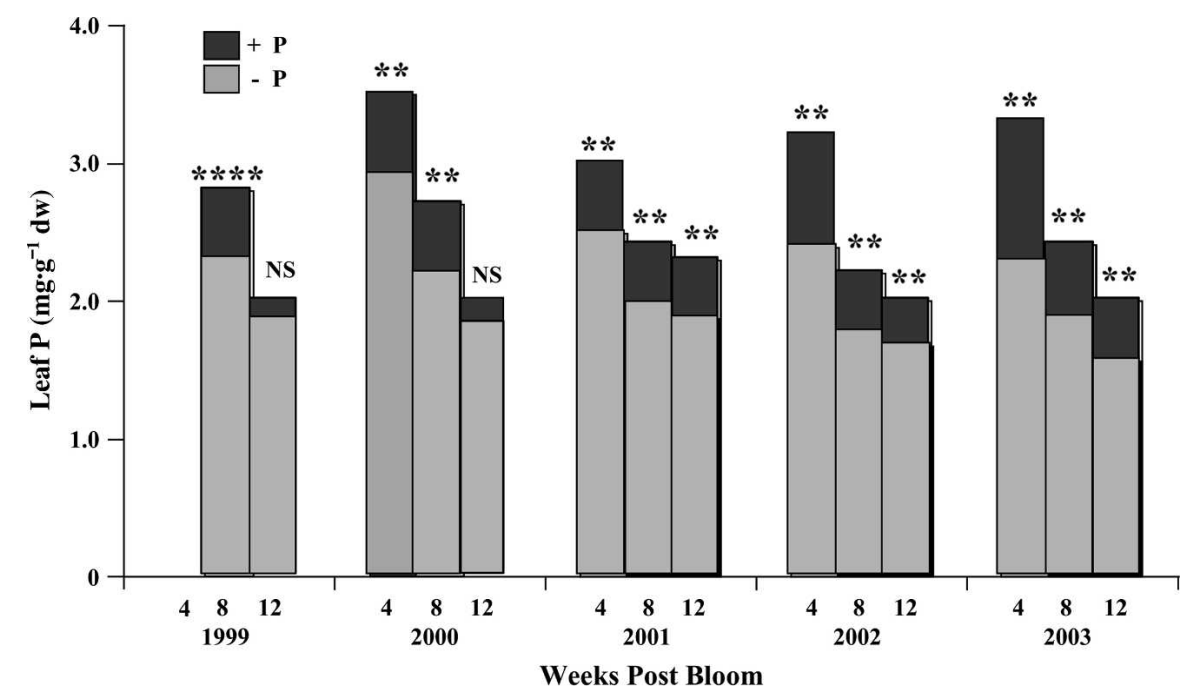

Fig. 2. Leaf phosphorus (P) concentration 4, 8, and 12 weeks postbloom as affected by fertigation of $20 \mathrm{~g} \mathrm{P}$ as ammonium polyphosphate $(+\mathrm{P})$ or not $(-\mathrm{P})$ for 'Fuji' apple, 1999 to 2003 . Paired means significantly different at $P=0.0001(* * * *), 0.01(* *)$, or nonsignificantly different (NS).

Table 2. Whole fruit phosphorus $(\mathrm{P})$ concentration at commercial harvest for apple cultivars [Ambrosia (A), Cameo (C), Fuji (F), Gala (G) and Silken (S)] as affected by fertigation of $20 \mathrm{~g}$ P as ammonium polyphosphate $(+\mathrm{P})$ or not $(-\mathrm{P})$ immediately after bloom, 1999 to 2003 .

\begin{tabular}{|c|c|c|c|c|c|c|c|c|c|}
\hline \multirow{3}{*}{$\begin{array}{l}\text { Treatment } \\
\text { cultivar }\end{array}$} & \multicolumn{9}{|c|}{ Fruit $\mathrm{P}\left(\mathrm{mg} \cdot \mathrm{kg}^{-1} \mathrm{fw}\right)$} \\
\hline & \multirow{2}{*}{$\begin{array}{c}1999 \\
\text { All }\end{array}$} & \multirow{2}{*}{$\begin{array}{c}2000 \\
\text { All }\end{array}$} & \multicolumn{5}{|c|}{$2001^{\mathrm{z}}$} & \multirow{2}{*}{$\begin{array}{c}2002 \\
\text { All }\end{array}$} & \multirow{2}{*}{$\begin{array}{c}2003 \\
\text { All }\end{array}$} \\
\hline & & & A & $\mathrm{C}$ & $\mathrm{F}$ & $\mathrm{G}$ & $\mathrm{S}$ & & \\
\hline$+\mathrm{P}$ & 158 & 128 & 110 & 129 & 145 & 107 & 129 & 102 & 131 \\
\hline$-\mathrm{P}$ & 129 & 97 & 84 & 90 & 106 & 90 & 99 & 78 & 109 \\
\hline Significance & $* * *$ & $* * * *$ & $* * * *$ & $* * * *$ & $* *$ & NS & $* *$ & $* * * *$ & $* *$ \\
\hline
\end{tabular}

${ }^{\mathrm{z}}$ Significant interaction between $\mathrm{P}$ treatment and cultivar only in 2001.

Ns, $, *, * * *, * * * * *$ Nonsignificant or paired means significantly different at $P=0.01,0.001$, or 0.0001 , respectively. 
surface applications of monoammonium phosphate (MAP) fertilizer (Raese, 1998). Application of $150 \mathrm{~g}$ of MAP fertilizer within the planting hole, in association with some form of soil disinfection, has improved establishment and initial growth of apple in replant problem orchards (Neilsen and Yorston, 1991). As a consequence of stimulation of second-year flowering by first-year P applications (Neilsen et al., 1990) and the effectiveness of first-year P fertigation (Neilsen et al., 1993), P fertigation of newly planted apple trees in the first year is a general commercial recommendation regardless of soil $\mathrm{P}$ and replant status (BC Ministry of Agriculture and Lands, 2007). The results reported here for a soil of low to moderate $\mathrm{P}$ status would suggest bloom time annual fertigation of $\mathrm{P}$ to trees receiving $\mathrm{N}$ and $\mathrm{K}$ fertigation should be recommended because cumulative yield over the first five growing seasons has increased by $\approx 20 \%(\approx 5.3 \mathrm{mT} /$ ha/year) for the five tested apple cultivars. It is also noteworthy that an increase in the number of fruit associated with $\mathrm{P}$ fertigation was not associated with the decrease in fruit size normally associated with higher crop loads (Goffinet et al., 1995).

Fruit quality. Standard quality characteristics of harvested fruit, including SSC, TA, fruit firmness, and percent red color, were unaffected by $\mathrm{P}$ fertigation (data not shown). The incidence of water core at harvest was assessed in the last 3 years of the study and in the 2 years of lowest harvest fruit $P$ concentration the incidence of water core was reduced for fruit fertigated with $\mathrm{P}$ (Table 4). In 2001, only 'Fuji' and 'Silken' exhibited water core, but for both of these cultivars, water core was reduced and for 'Silken' completely eliminated. In 2002, the reduction in water core was significant across all cultivars. The effect was not observed in 2003 when crop load was low for all cultivars. In 2001 and 2002, the low P years, membrane leakage of 'Fuji' and 'Silken' apple, which were most susceptible to water core at harvest, was reduced in both cultivars (Table 5). Water and lipid-soluble antioxidant concentration was higher for all Ptreated fruit, except 'Gala' in 2002 (Table 6 ). In 2002, the degree of browning of cut apple slices from stored fruit was inhibited for all apple cultivars in fruit that received $\mathrm{P}$ at bloom (Table 7).

Fertigation of $\mathrm{P}$ had no effects on SSC, TA, firmness, or color at harvest, indicating the increased yield associated with $\mathrm{P}$ application did not negatively affect standard fruit quality characteristics. Beneficial effects of elevated apple fruit $\mathrm{P}$ concentrations on incidence of low-temperature breakdown (Johnson and Yogoratnam, 1978), including fruit firmness (Webster and Lidster, 1986), have been periodically reported. From these earlier studies, critical P fw concentration thresholds were recommended to exceed 90 $\mathrm{mg} \cdot \mathrm{kg}^{-1}$ for 'McIntosh' and $110 \mathrm{mg} \cdot \mathrm{kg}^{-1}$ for 'Cox's Orange Pippin' for maximum apple quality. Although such thresholds are likely to vary with cultivar, $\mathrm{P}$ concentrations of fruit

Table 3. Annual and cumulative fruit number, fruit size and per tree yield for apple cultivars [Ambrosia (A), Cameo (C), Fuji (F), Gala (G) and Silken (S)] as affected by fertigation of $20 \mathrm{~g} \mathrm{P}$ as ammonium polyphosphate $(+\mathrm{P})$ or not $(-\mathrm{P})$ immediately after bloom, 1999-2003.

\begin{tabular}{|c|c|c|c|c|c|c|c|c|c|c|}
\hline \multirow{3}{*}{$\begin{array}{l}\text { Treatment } \\
\text { cultivar }\end{array}$} & \multicolumn{10}{|c|}{ Fruit number (n/tree) } \\
\hline & \multirow{2}{*}{$\begin{array}{l}1999 \\
\text { All }\end{array}$} & \multirow{2}{*}{$\begin{array}{c}2000 \\
\text { All }\end{array}$} & \multicolumn{5}{|c|}{$2001^{z}$} & \multirow{2}{*}{$\begin{array}{c}2002 \\
\text { All }\end{array}$} & \multirow{2}{*}{$\begin{array}{c}2003 \\
\text { All }\end{array}$} & \multirow{2}{*}{$\begin{array}{c}\text { 1999-2003 } \\
\text { All }\end{array}$} \\
\hline & & & $\mathrm{A}$ & $\mathrm{C}$ & $\mathrm{G}$ & $\mathrm{F}$ & $\mathrm{S}$ & & & \\
\hline$\overline{+P}$ & 8 & 49 & 74 & 52 & 47 & 98 & 73 & 71 & 40 & 239 \\
\hline$-\mathrm{P}$ & 9 & 40 & 61 & 48 & 42 & 81 & 63 & 66 & 28 & 203 \\
\hline Significance & NS & NS & $*$ & NS & NS & $*$ & NS & NS & $*$ & $*$ \\
\hline & \multicolumn{10}{|c|}{ Fruit size (g/fruit) } \\
\hline Cultivar & All & All & & & All & & & All & All & All \\
\hline$+\mathrm{P}$ & 244 & 217 & & & 203 & & & 211 & 205 & 199 \\
\hline$-\mathrm{P}$ & 214 & 200 & & & 197 & & & 204 & 209 & 194 \\
\hline Significance & \multicolumn{9}{|c|}{ Yield (kg/tree) } & NS \\
\hline Cultivar & All & All & A & $\mathrm{C}$ & $\mathrm{G}$ & $\mathrm{F}$ & $\mathrm{S}$ & All & All & All \\
\hline$+\mathrm{P}$ & 2.0 & 10.3 & 13.2 & 12.1 & 12.2 & 15.1 & 12.5 & 14.1 & 7.7 & 47.2 \\
\hline$-\mathrm{P}$ & 1.9 & 7.7 & 10.8 & 11.5 & 10.5 & 13.5 & 10.2 & 13.0 & 5.7 & 39.3 \\
\hline Significance & NS & $* * *$ & $*$ & NS & NS & NS & NS & NS & $* *$ & $*$ \\
\hline
\end{tabular}

${ }^{\mathrm{z}}$ Significant interaction between $\mathrm{P}$ treatment and cultivar for fruit number and yield in 2001 only. Ns, ${ }^{* * *, * * *, * * * *}$ Nonsignificant or paired means significantly different at $P=0.05,0.01,0.001,0$ or 0.0001 , respectively.

Table 4. Incidence of water core at harvest for apple cultivars [Ambrosia (A), Cameo (C), Fuji (F), Gala $(\mathrm{G})$ and Silken $(\mathrm{S})]$ as affected by fertigation of $20 \mathrm{~g}$ phosphorus $(\mathrm{P})$ as ammonium polyphosphate $(+\mathrm{P})$ or not (-P) immediately after bloom, 2001 to 2003.

\begin{tabular}{|c|c|c|c|c|}
\hline \multirow{3}{*}{$\begin{array}{l}\text { Treatment } \\
\text { cultivar }\end{array}$} & \multicolumn{4}{|c|}{ Proportion of apple fruit affected by water core } \\
\hline & \multicolumn{2}{|c|}{$2001^{z}$} & \multirow{2}{*}{$\begin{array}{c}2002 \\
\text { All }\end{array}$} & \multirow{2}{*}{$\begin{array}{c}2003 \\
\text { All }\end{array}$} \\
\hline & $\mathrm{F}$ & $\mathrm{S}$ & & \\
\hline$+\mathrm{P}$ & 0.62 & 0.00 & 0.22 & 0.27 \\
\hline$-\mathrm{P}$ & 0.88 & 0.16 & 0.29 & 0.29 \\
\hline Significance & $* * *$ & $*$ & $*$ & NS \\
\hline
\end{tabular}

${ }^{z}$ Significant interaction between $P$ treatment and cultivar in 2001. No water core observed for A, C, or G cultivars this year.

${ }_{\mathrm{Ns}, *, * * * *}$ Nonsignificant or paired means significantly different at $P=0.05$ or 0.001 , respectively.

not receiving $\mathrm{P}$ in our study were usually less than $100 \mathrm{mg} \cdot \mathrm{kg}^{-1} \mathrm{fw}$ in 2001 and 2002 (an exception was 'Fuji' apple at $106 \mathrm{mg} \cdot \mathrm{kg}^{-1}$ in 2001). In these years, trees fertigated with $P$ had fruit $\mathrm{P}$ concentrations in excess of these minimum values. These fruit were characterized by improved membrane stability as indicated by reduced incidence of water core at harvest, reduced membrane leakage, and susceptibility to browning and increased antioxidant content after $90 \mathrm{~d}$ of cold air storage. These results are sufficient to justify further research to clarify the relationship between fruit $\mathrm{P}$ concentration and these indicators of fruit quality over a wider range of cultivars, seasons, and storage conditions.

\section{Conclusions}

A single, annual application of $20 \mathrm{~g}$ P per tree at bloom as ammonium polyphosphate dissolved in irrigation water was beneficial for the performance, over the first five fruiting seasons, of a range of apple cultivars, including 'Fuji', 'Gala', 'Ambrosia', 'Silken', and 'Cameo' planted at high density on the dwarfing rootstock M.9. These trees were also receiving optimum fertigation recommendations for sandy soils, which included daily application of $168 \mathrm{mg} \cdot \mathrm{L}^{-1} \mathrm{~N}$ as calcium nitrate, maintenance $\mathrm{B}$ applications $(0.17 \mathrm{~g} \mathrm{~B}$ per tree as Solubor) both applied 0 to 4 weeks postbloom, and daily applications of $\mathrm{K}$ applied 8 to 12 weeks postbloom as potassium chloride ( $\approx 20 \mathrm{~g} \mathrm{~K}$ per tree). The results
Table 5. Membrane leakage of 'Fuji' and 'Silken' apples after $90 \mathrm{~d}$ storage at $1{ }^{\circ} \mathrm{C}$ as affected by fertigation of $20 \mathrm{~g}$ phosphorus $(\mathrm{P})$ as ammonium polyphosphate $(+\mathrm{P})$ or not $(-\mathrm{P})$ immediately after bloom in 2001 and 2002. ${ }^{\mathrm{z}}$

\begin{tabular}{lccccc}
\hline & \multicolumn{2}{c}{ Fuji } & & \multicolumn{2}{c}{ Silken } \\
\cline { 2 - 3 } \cline { 5 - 6 } Treatment & 2001 & 2002 & & 2001 & 2002 \\
\hline$+\mathrm{P}$ & 0.19 & 0.19 & & 0.17 & 0.20 \\
$-\mathrm{P}$ & 0.28 & 0.33 & & 0.28 & 0.27 \\
Significance & $* *$ & $* *$ & & $* *$ & $*$ \\
\hline
\end{tabular}

${ }^{\mathrm{z}}$ Membrane leakage was determined as the ratio of ultraviolet absorbing leakage during $1 \mathrm{~h}$ at $20^{\circ} \mathrm{C}$ for intact tissue over the total ultraviolet absorbing solute content of the same tissue after freezing and thawing.

${ }^{*, * *}$ Paired means significantly different at $P=0.05$ or $P=0.01$

imply that conventional fertigation recommendations for $\mathrm{P}$, which currently advise $\mathrm{P}$ application only in the first year, should be modified to include annual bloom-time $\mathrm{P}$ application. A question is also raised as to whether continuous fertigation of $\mathrm{P}$ would provide additional benefits.

Application of $\mathrm{P}$ in this manner, timed to coincide with a period of high shoot, fruit, and root growth around bloom, is highly effective as indicated by its mobility in applied water throughout the rooting zone and its ability to increase leaf $P$ concentration throughout the growing season and fruit $\mathrm{P}$ concentration at harvest. Furthermore, cumulative yield of these trees was increased by $\approx 20 \%$ for all tested apple cultivars during the 
Table 6. Water-soluble (WSA) and lipid-soluble antioxidant (LSA) concentrations of 'Fuji' (F), 'Silken' (S), 'Ambrosia' (A), 'Cameo' (C), and 'Gala' (G) apples after $90 \mathrm{~d}$ storage at $1{ }^{\circ} \mathrm{C}$ as affected by fertigation of $20 \mathrm{~g}$ as ammonium polyphosphate $(+\mathrm{P})$ or not $(-\mathrm{P})$ immediately after bloom in 2001 and 2002.

\begin{tabular}{lccccccc}
\hline & & \multicolumn{2}{c}{$\mathrm{F}$} & $\mathrm{S}$ & $\mathrm{A}$ & $\mathrm{C}$ & $\mathrm{G}$ \\
\cline { 3 - 8 } Antioxidant & Treatment & 2001 & 2002 & 2002 & 2002 & 2002 & 2002 \\
\hline WSA $\left(\mu \mathrm{g} \cdot \mathrm{mL}^{-1}\right.$ ascorbate) & $+\mathrm{P}$ & 0.58 & 0.49 & 0.77 & 0.74 & 0.44 & 0.70 \\
& $-\mathrm{P}$ & 0.45 & 0.38 & 0.39 & 0.41 & 0.28 & 0.63 \\
Significance & & $* *$ & $* *$ & $* *$ & $* *$ & $* *$ & NS \\
LSA $\left(\mu \mathrm{g} \cdot \mathrm{mL}^{-1}\right.$ tocopherol) & $+\mathrm{P}$ & 1.32 & 1.80 & 1.58 & 1.27 & 2.28 & 1.60 \\
& $-\mathrm{P}$ & 1.12 & 1.32 & 1.33 & 0.84 & 1.44 & 1.34 \\
Significance & & $* *$ & $*$ & $*$ & $*$ & $* *$ & $* *$ \\
\hline
\end{tabular}

Ns,*,*** Nonsignificant or paired means significantly different at $P=0.05$ or 0.01 , respectively.

Table 7. L value of 'Silken' (S), 'Gala' (G), 'Ambrosia' (A), 'Fuji' (F), and 'Cameo' (C) apple slices after $90 \mathrm{~d}$ storage at $1{ }^{\circ} \mathrm{C}$ as affected by fertigation of $20 \mathrm{~g}$ phosphorus $(\mathrm{P})$ as ammonium polyphosphate $(+\mathrm{P})$ or not (-P) immediately after bloom in $2002 .^{\mathrm{z}}$

\begin{tabular}{lccccc}
\hline Treatment & S & G & A & F & C \\
\hline$+\mathrm{P}$ & 77.4 & 79.0 & 77.3 & 75.5 & 77.9 \\
$-\mathrm{P}$ & 76.4 & 78.2 & 76.6 & 73.8 & 77.0 \\
Significance & $* *$ & $* *$ & $*$ & $* *$ & $* *$ \\
\hline
\end{tabular}

${ }^{\mathrm{z}}$ Color of slices was determined $5 \mathrm{~d}$ after slicing and storage at $5{ }^{\circ} \mathrm{C}$ in zip-lock packages with a Minolta chromometer. A higher $\mathrm{L}$ value denotes a lighter color for the slice surface (i.e., less browning).

${ }^{* * * *}$ Significantly different at $P=0.01$ and 0.05 , respectively.

first five growing seasons. These yield increases were associated with maintenance of standard fruit quality parameters, including average size, SSC, TA, and proportion of coloration (for red-skinned cultivars) at harvest. Reduction in incidence of water core at harvest, resistance to browning of cut slices, reduced membrane leakage, and elevated antioxidant content of fruit after cold air storage indicated a role for $\mathrm{P}$ in maintenance of apple fruit membrane stability. Cumulative results from this research also suggested optimum midsummer leaf $\mathrm{P}$ concentrations should exceed $2.2 \mathrm{mg} \cdot \mathrm{g}^{-1} \mathrm{dw}$ for fruiting, fertigated high-density apple orchards, much in excess of current recommendations of 1.5 $\mathrm{mg} \cdot \mathrm{g}^{-1} \mathrm{dw}$. Associated recommended harvest fruit $\mathrm{P}$ concentrations would then be 100 to $120 \mathrm{mg} \cdot \mathrm{kg}^{-1} \mathrm{fw}$.

\section{Literature Cited}

Benson, N.R. and R.P. Covey, Jr. 1979. Phosphorus nutrition of young 'Golden Delicious' apple trees growing in gravel culture. J. Amer. Soc. Hort. Sci. 104:682-685.

Bould, C. and R.I. Parfitt. 1973. Leaf analysis as a guide to the nutrition of fruit crops. X. Magnesium and phosphorus sand culture experiments with apple. J. Sci. Food Agr. 24:175-185.

Boyton, D. and G.H. Oberly. 1966. Apple nutrition, p. 1-50. In: Childers, N.F. (ed.). Nutrition of fruit crops. Horticultural Publications, New Brunswick, NJ.

British Columbia Ministry of Agriculture and Lands. 2007. Integrated fruit production guide for commercial fruit growers. Interior districts, Victoria, BC, Canada.

Cripps, J.E.L. 1987. Response of apple trees to soil applications of phosphorus, nitrogen and potassium. Aust. J. Exp. Agr. 27:909-914.
Edwards, J.H., R.R. Bruce, B.D. Horton, J.L. Chesness, and E.J. Wehunt. 1982. Soil cation and water distribution as affected by NH4NO3 applied through a drip irrigation system. J. Amer. Soc. Hort. Sci. 107:1142-1148.

Gil, M.I., J.R. Gorny, and A.A. Kader. 1998. Responses of 'Fuji' apple slices to ascorbic acid treatment and low-oxygen atmospheres. HortScience 33:305-309.

Goffinet, M.C., T.L. Robinson, and A.N. Lakso. 1995. A comparison of 'Empire' apple fruit size and anatomy in unthinned and handthinned trees. J. Hort. Sci. 70:375-387.

Johnson, D.S. and N. Yogoratnam. 1978. The effects of phosphorus sprays on the mineral composition and storage quality of Cox's Orange Pippin apples. J. Hort. Sci. 53:171178.

Klein, I. and G. Spieler. 1987. Fertigation of apples with nitrate or ammonium nitrogen under drip irrigation. II. Nutrient distribution in the soil. Commun. Soil Sci. Plant Anal. 18:323-339.

Neilsen, D., P. Parchomchuk, and E.J. Hogue. 1993. Soil and peach seedling responses to soluble phosphorus applied in single or multiple doses. Commun. Soil Sci. Plant Anal. 24:881-898.

Neilsen, D., P. Parchomchuk, G.H. Neilsen, and E.J. Hogue. 1998. Using soil solution monitoring to determine the effects of irrigation management and fertigation on nitrogen availability in high density apple orchards. J. Amer. Soc. Hort. Sci. 123:706-713.

Neilsen, G.H., E.J. Hogue, and P. Parchomchuk. 1990. Flowering of apple trees in the second year is increased by first-year $\mathrm{P}$ fertilization. HortScience 25:1247-1250

Neilsen, G.H., P.B. Hoyt, and D. Neilsen. 1995. Soil chemical changes associated with NPfertigated and drip irrigated high-density apple orchards. Can. J. Soil Sci. 75:307-310.

Neilsen, G.H. and D. Neilsen. 2003. Nutritional requirements of apple, p. 267-302. In: Ferree, D.C. and I.J. Warrington (eds.). Apples, botany, production and uses. CABI Publishing, Oxon, UK.

Neilsen, G.H., D. Neilsen, and F. Peryea. 1999. Response of soil and irrigated fruit trees to fertigation or broadcast application of nitrogen, phosphorus, and potassium. HortTechnology 9:393-401.

Neilsen, G.H., P. Parchomchuk, R. Berard, and D. Neilsen. 1997. Irrigation frequency and quantity affect root and top growth of fertigated 'McIntosh' apple on M.9, M.26 and M.7 rootstock. Can. J. Plant Sci. 77:133-139.

Neilsen, G.H., P. Parchomchuk, W.D. Wolk, and O.L. Lau. 1993. Growth and mineral composition of newly planted apple trees following fertigation with $\mathrm{N}$ and P. J. Amer. Soc. Hort. Sci. 118:50-53.

Neilsen, G.H. and J. Yorston. 1991. Soil disinfection and monoammonium phosphate fertilization increase precocity of apples on replant problem soils. J. Amer. Soc. Hort. Sci. 116:651-654.

O’Neil, M.K., B.R. Gardner, and R.L. Roth. 1979. Orthophosphoric acid as a phosphorus fertilizer in trickle irrigation. Soil Sci. Soc. Amer. J. 43:283-286.

Parchomchuk, P., R.C. Berard, and T.W. Van der Gulik. 1996. Automatic irrigation scheduling using an electronic atmometer, p. 1099-1104. In: Camp, C.R., E.J. Sadler, and R.E. Yoder (eds.). Evapotranspiration and irrigation scheduling. Amer. Soc. Agr. Engn. Proc. Intl. Conf., San Antonio, TX.

Raese, J.T. 1998. Response of apple and pear trees to phosphate fertilization: A compendium. Commun. Soil Sci. Plant Annal. 29:17991821.

SAS. 1989. SAS/STAT. User's guide. Vers. 6, Vol. 2. SAS Inst., Cary, NC.

Shear, C.B. and M. Faust. 1980. Nutritional ranges in deciduous tree fruits and nuts. Hort. Rev. (Amer. Soc. Hort. Sci.) 2:142-163.

Sweeney, R.A. and P.F. Rexroad. 1987. Comparison of LECO FP-228 'Nitrogen Determinator' with AOAC copper catalyst Kjeldahl method for crude protein. J. Assn. Off. Anal. Chem. 70:1028-1030.

Taylor, B.K. and F.H. Goubran. 1975. The phosphorus nutrition of the apple tree. I. Influence of rate of application of superphosphate on the performance of young trees. Aust. J. Agr. Res. 26:843-853.

Toivonen, P.M.A., P. Delaquis, M. Cliff, T. Beveridge, and L. Moyls. 2003. Development of apple quality standards for slicing and optimization of sanitation procedures. Final report, p. 119-128. In: 2003 apple post harvest research review. Washington Tree Fruit Research Commission, Wenatchee, WA.

Webster, D.H. and P.D. Lidster. 1986. Effects of phosphate sprays on McIntosh apple fruit and leaf composition, flesh firmness and susceptibility to low-temperature disorders. Can. J. Plant Sci. 66:617-626.

Wittneben, U. 1986. Soils of the Okanagan and Similkameen Valleys. Ministry of Environment Technical Report 10. British Columbia Soil Survey, Report 52, Victoria, BC, Canada.

Wolk, W.D., O.L. Lau, G.H. Neilsen, and B.G. Drought. 1998. Factors and time of sample collection for correlating storage potential of 'McIntosh', 'Spartan' and 'Golden Delicious' apples. J. Amer. Soc. Hort. Sci. 123:104-109. 